\title{
Anthropology between Heritage and Museums
}

José Guilherme Cantor Magnani

\begin{abstract}
By analyzing some cases this article exposes the contribution of Anthropology, and specially, Urban Anthropology to the characterization of what may or may not be a cultural good and its value as Heritage in the context of the urban landscape. As a matter of fact, here it is shown the application of the ethnographic method, with its "inside and close-by" regard and with the categories of turf, patch, route and circuit, developed along researches performed at the Núcleo de Antropologia Urbana (NAU/USP) [Urban Anthropology Nucleus]. Thus, our aim is to argument that this work brings forth new elements for a better definition of the many heritage modalities - be it Architectonic, Archeological, Historical, and mainly the so-called Immaterial or Intangible. Thereby a fecund dialogue is opened between Anthropology and the disciplines traditionally engaged with the fields of Heritage and Museology.
\end{abstract}

Keywords: Urban Anthropology, Cultural Heritage, Patch, Route \& circuit, City Museum, Urban Landscape.

\section{Resumo}

Este artigo apresenta, a partir da análise de alguns casos, a contribuição da Antropologia, e em especial da Antropologia Urbana, para a caracterização do que seja um bem cultural e de seu valor de patrimônio no contexto da paisagem urbana. Mais concretamente, é mostrada a aplicação do método etnográfico, com seu olhar de "perto e de dentro", e das categorias pedaço, mancha, trajeto e circuito, desenvolvidos em pesquisas do Núcleo de Antropologia Urbana (NAU/USP). Pretende-se, desta forma, argumentar que esta contribuição pode aportar novos elementos para uma melhor definição das várias modalidades de patrimônio - arquitetônico, arqueológico, histórico, e 
principalmente do chamado imaterial ou intangível. Abre-se, assim, assim um fecundo diálogo com as disciplinas tradicionalmente comprometidas com os campos do patrimônio e da museologia.

Palavras-chave: Antropologia Urbana, patrimonio cultural, mancha, trajeto \& circuito, museu da cidade, paisagem urbana 


\section{Anthropology between Heritage and Museums}

José Guilherme Cantor Magnani

\section{Introduction: An art cinema}

In March 2010, the HSBC bank formally discontinued its sponsorship of the Cine Belas Artes movie theater complex located at the corner of Rua da Consolação and Avenida Paulista. It was regarded as an art theater that featured independent films outside of mainstream moviemaking where each of the theater had suggestive names such as Villa-Lobos, Candido Portinari, Oscar Niemeyer, Aleijadinho and Carmen Miranda.

This decision mobilized various sectors of São Paulo's cultural scene, and in July 2010 the Movimento pelo Cine Belas Artes (MBA) (Movement for the Cine Belas Artes) launched a campaign to assure that the movie theater complex would survive. As a further precaution, the MBA solicited preservation status from the Council for the Preservation of Historic and Environmental Heritage of the City of São Paulo (CONPRESP) in January 2011. The owner reacted by demanding either an increase in rent or that the movie complex abandon the building dispossession of the building. In March 17, 2011, the cinema closed its doors, which led to an intense mobilization: public demonstrations, articles in newspapers and blogs, complaints about cultural and artistic neglect, and debates about history and heritage in the city. After all since 1943 the movie theater complex had existed previously under the name of Trianon.

The commotion over the Cine Belas Artes continued as the CONPRESP refused the request. What, CONPRESP asked, would be there to preserve? According to its protocol, only a building itself can be considered, and it did not have any architectural value that would justify the measure. The public retaliated with cultural arguments and the state attorney general filed a lawsuit that led the $13^{\text {th }}$ Jurisdiction of the Public Treasury court to order the theater be reopened. Then, a state entity, the Council for the Defense of 
Historic, Artistic and Touristic Heritage (CONDEPHAAT), accepted a new preservation appeal, and even the city council joined the struggle, creating an Investigatory Committee and summoning the CONPRESP director to testify.

The commotion of all these actors over this issue is remarkable, but even more interesting is how this controversy involved almost all of the familiar aspects of heritage: architecture, art, history, and even the most recent: the immaterial. Just a few months earlier something similar had occurred with Parque da Água Branca (Água Branca Park), which is protected by CONDEPHAAT and which, through the initiative of a wife of a São Paulo mayor during her brief stay in government, began to conduct "improvements" and reforms without any of the customary measures, even legal ones. As a result, an association called Friends of Parque da Água Branca alerted the media, and contacted several government offices; the situation is still unresolved. ${ }^{1}$

I use these anecdotes to begin my discussion about "New Subjects, New Technologies, and New Uses of Museology and Preservation," the theme proposed in this edition of Vibrant, because they illustrate the internal incongruities of several concepts of heritage. The limits of legal measures supposedly designed to protect public heritage, and the repercussions of these debates beyond the circle of the relevant technical institutions, provides a good opportunity to place the issue in another analytical framework.

The case of the Cine Belas Artes is particularly interesting for this reflection to the degree that it is located inside a specific patch ${ }^{2}$ that was described

1 In the article "Two Years Without the Cine Belas Artes: there is something to commemorate!" published in national magazine Carta Capital on March 21st 2013, Nabil Bonduki, Professor "livre-docente" of city planning at the Faculdade de Arquitetura e Urbanismo (FAU) from the Universidade de São Paulo (USP), who is also a city councilman in São Paulo and responsible for drafting the new master plan for the city, commemorates the reversal of the closing after the mobilization by the Movimento Pelo Cine Belas Arte (MBA) - which received over 100,00o signatures via the internet in defense of the movie theater complex. "CONDEPHAAT granted heritage status to the building's façade and the memory of the cinema was registered. Any other work or physical alteration can only be performed with authorization of the institution. It is expected that with the city's new administrative council, the CONPRESP - which two years earlier began the process of seeking heritage status - will be able to resume the issue which had come to appear positive in the technical area".

2 "Patches" is a term we use to describe contiguous areas within the urban space endowed with infrastructure that marks their limits and facilitates a predominant activity or practice - each one specific, always competing and complementing. The category was proposed to describe a specific established spatial arrangement within the urban landscape. It is distinct from the category of turf, which is related to the dynamics of the group that identifies it. At any moment the users of a turf can choose another space as a point of reference and meeting place. The patch, on the other hand, results from the inherent relation between various components of the urban infrastructure which serves as the appeal to the flux 
and analyzed in 1991 by the Núcleo de Antropologia Urbana (NAU) (Urban Anthropology Nucleus). ${ }^{3}$ At that time, the movie theater, along with the Riviera Bar, was one of the central structural elements of the social dynamics at the corner of Rua da Consolação Street and Avenida Paulista.

It is worth describing the Riviera Bar because of the complimentary role it played within this patch, serving as a kind of partner of the Cine Belas Artes. Given the name Riviera in 1949, it was a place frequented by families, judges and doctors that served sandwiches, tea, and ice cream. In the late 1950 it became popular among students from the São Francisco Law School and Mackenzie University. During the 6os, it was a meeting point for many activists of various political tendencies (and therefore suffered frequent police raids), and for a public connected to the art scene: theatre, movies and music. It served as the setting of the movie "Besame Mucho" (which depicted the period of the dictatorship), and inspired a song by Sá and Guarabira ("We were like that at the time of Riviera blue"), as well as the cartoonist Angeli and his characters "Rê Bordosa", "Meia Oito," and "Juvenal." The latter was a waiter who worked at the bar for more than thirty years (Torres, 2008: 75).

The Baguette Grill and Pasta House, the Chamego bar, Nostromondo gay club, the Belas Artes bookstore, the Metrópolis bar, the Kairós bookstore and many street stands selling books - among other features — completed this patch of gatherings, culture, and leisure, traversed by the various routes ${ }^{4}$ used by passers-by in their various choices and preferences. This scenario, however, has changed: the Riviera Bar closed in 2006, along with most of the establishments that contributed to that particular ambiance and attracted the flux of people to that space.

of visitors. A patch is more anchored to the landscape than to the passing populations that frequent it. Thus the way users identify with a patch is different than the way users identify with their turf. The patch is more open, receives more, and more diverse, people, and offers them not a sense of welcome or belonging through any given service or good, but the possibility of encounter. The patch beckons to the unexpected, more than to the expected: it is not possible to know for sure what or who we are going to meet in a patch - even if we have an idea of the type of goods or services that are offered there and of the taste, or the general consumption pattern, of its visitors" (Magnani, 2007:20).

3 The Núcleo de Antropologia Urbana is a research group coordinated by Professor José Guilherme Cantor Magnani since 1990 at the University of São Paulo. See more information: www.n-a-u.org. TN

4 A description of one of those routes: people arrived with a certain anticipation, bought their tickets, and enjoyed the wait before the film started by drinking coffee or having a bite across the street. When the session ended, everyone headed to the Rivera bar (the more intellectual types) or to the Metrópolis (for the more flirtatious). Whether before or after, everyone strolled by the bookstores, while hours later, the enthusiasts wandered to the nightclubs. 
The regulars headed off in the direction of Augusta Street, around the Espaço Unibanco (now called Espaço Itaú de Cinema), and the Frei Caneca Shopping Center and its movie theaters. That segment of the street, known as the Baixa (or lower) Augusta leads downtown - in opposition to the segment that leads towards Jardins, an elite neighborhood. - It has recently displayed a new vitality. Previously known as an erotic leisure space, home to mixed saunas, call girls and transvestites waiting at corners, the range of use and enjoyment of the space has expanded. New bars aimed at college students have opened, as well as coffee shops, music and bookstores, and indie rock houses. As a consequence, new actors began to circulate, this includes a "straight edge" scene and a more sophisticated gay public, for example, besides the already mentioned moviegoers.

The old patch anchored at the corner of Avenida Paulista and Rua da Consolação, once effervescent in terms of cultural consumption, is now a place of passage: bus stops and exclusive bus lanes, an intense flow of cars, and right next to the old cinema, the entrance to a new subway line. If it was once a place where people paused in search of leisure and comfort, it is now a place marked by the speed of the daily commute.

The discussion concerning the permanence (or not) of the Cine Belas Artes is directly linked to the transformations of the place, which leads me to consider the role of cultural goods and their value as heritage in both the context of the cityscape and the web of routes of passersby. In this case, the anthropological perspective - and especially the perspective of urban anthropology, and the research theories and methodologies developed at the NAU — can lend clarity to the debate.

\section{Parque do Povo (People's Park)}

The Núcleo de Antropologia Urbana has a history linked to questions concerning heritage and museums. Among its various encounters and achievements, one should be highlighted: the restoration of the Parque do Povo (People's Park) by the CONDEPHAAT in São Paulo in 1994. The development of this restoration process relied not only on the aid of historical and environmental foundations, but also on a research report based on fieldwork conducted by NAU that examined a specific practice that took place there: amateur soccer. 
An article published by the Revista do Patrimônio (Magnani \& Morgado, 1996) emphasized the novelty of the case. The article begins by recalling that the preservation of spaces such as candomble terreiros, the sites of former quilombos, factory villages, buildings where migrant communities live, and other similar spaces - spaces linked to the lifestyles (in terms of housing, work, religion) of socially and/or ethnically marked groups - hardly surprised anyone. Although it is uncommon, the inclusion of these items on the official cultural heritage list shows the presence of values that broaden the traditional criteria that reign at preservation and restoration institutions.

The preservation of the Parque do Povo was somehow different from the places cited above: it was an area of $150.000 \mathrm{~m}^{2}$, located in an elite neighborhood, in fact, one of the most expensive regions of São Paulo. ${ }^{5}$ The area was divided into soccer fields that were used by "amateur" teams: the Marítimo Futebol Clube, Grêmio Esportivo Canto do Rio, Tintas Cirota, Sociedade Esportiva Flor do Itaim, and others that organized noisy and frequent contests in the form of daily "tournaments" and "festivals," attracting visitors from the most diverse and distant neighborhoods of São Paulo. The Park also hosted a circus and a theater where dances where held on weekends.

If what initially justified the demand for preservation was the need to maintain a green space, considering the city's environmental quality, it was the continuous presence of amateur soccer teams at the site, at least since the 1930s, which became the main reason for preserving the park. The region had been the site of one of the many riverside meadows in the city - in this case along the Pinheiros River - that were traditionally used for leisure activities on weekends, and which have gradually been incorporated into the city through the urbanization process.

The of the Parque do Povo, however, persisted, and not just as a mere testament or vestige of an old mode of use, but actively thrived. Yet there was an increasing dissonance between it and the sophisticated environs that came to surround it. And here began the saga of a process quite different than those that normally occur at preservation and restoration institutions.

In the first place, the question involved a space related to a leisure activity - note that at that time the discourse about "Immaterial Heritage" did not

5 It is located in the Itaim Bibi neighborhood, and is bordered by the Juscelino Kubistchek, Cidade Jardim, Brigadeiro Haroldo Veloso avenues and the Pinheiros highway. 
exist. Activities of home, work, or religion were the aspects usually invoked to justify the preservation of places of worship, work settings and facilities, or examples of unique construction types. Besides the fields and grounds marked with lime and the usual park improvements, the park did not exhibit any architectonic or artistic quality.

Secondly, despite the proven historical link of the present practice with the original use of the land, it was a popular kind of leisure that had nothing to do with the image of the picnics of old along the whimsical rivers that meander through São Paulo offering delightful settings for family recreation. Currently the bodies, colors, odors, uniforms, verbal expressions, and dust from the fields all blend into a repertoire that clash with the aesthetics of the surrounding buildings, the behavior of the passersby and residents and the various models of cars, all of which belong to the upper classes.

For some, the Parque do Povo - beginning with the name - would be better off at the outskirts of the city. Of course, the regions for the elite can cohabit with "those people" at the expected hours, as long as they wear work uniforms and use the appropriate speech. But, for their recreation? The game of inversions and contrasts however, goes farther. Everyone knows that weekends are for leisure, but at the there were soccer games on weekdays. Just who was using the park? Honest, hard-working people? Where di they come from? The research challenged the suspicion that they were "good-for-nothings" playing on a Monday, a workday. We discovered that they were workers (and union members at that) from the restaurants, hotels and other establishments whose day off is Monday.

The proposal was to remove that "wound," as some people came to call the park, and replace it with alternatives that would better suit the surroundings: a glamorous shopping center, a beautifully landscaped park or even an apartment complex, something in a postmodern style, much more in keeping with the style of the recent occupation along the Pinheiros highway in front. Everything, of course, within the parameters of a suitable landscape. Meanwhile, some users of the fields organized themselves, an association emerged, and support was sought in the media, the city council, and the university. Finally, after many unpredictable changes, the Parque do Povo was granted cultural heritage status, ensuring the right to leisure, and a form of leisure with popular characteristics, in a space that had been used as such for many years. 
Unfortunately, twelve years have gone by and nothing remains from the original proposal for declaring the park a heritage site, as the city government's current website shows:

The Park is set within an area that belongs to the Caixa Econômica Federal ${ }^{6}$ and to the Instituto Nacional do Seguro Social7. For over 20 years, about 11 sport clubs have used the site. The city council put an end to this use of the space in 2006. The educational and environmental plan for the Park includes seven self-guided paths, with plants that compose the botanical collection of the park. Among them, there is the aromatic and medicinal plant collection that composes the Sensitive Garden. The species found in the garden awaken touch, smell, and taste. People can touch, smell, and even bite the leaves of the plants and trees to get to know them."

Well, these "illegal occupants" (who had been there for over 20 years!) were exactly the social actors whose practice had motivated the preservation of the Park, a bit of history that is not even mentioned in the website. But now that the unwanted visitors are kept away, it is possible to touch, smell, and bite the leaves of the aromatic plants.

As you can see, preservation is not always the best mechanism for promoting -both promptly and with positive results - the defense of any specific property (recall the case of Cine Belas Artes). Nor can it guarantee their appropriate protection (Parque da Água Branca and Parque do Povo). Goods without material and or tangible, lasting support (like the soccer fields traced into the land with lime) are more vulnerable, as are spaces related to the practices of social agents with limited powers to negotiate. This is what happened at the Parque do Povo when not even the prestigious institutions involved in the dispute were able to guarantee the preservation of the popular soccer fields.

6 According to its official website [www.caixa.gov.co], the Caixa Econômica Federal bank is owned completely by the federal government. It plays a fundamental role in the promotion of urban development and social justice in the country. The Caixa is dedicated to helping low-income people to improve their lifestyle. (Accessed on 12-04-2013, 11:50).

7 The Instituto Nacional do Seguro Social (INSS) [www.mpas.gov.br] is the entity responsible for the country's Social Security system. Its main function is to guarantee workers' and their families portection and welfare. (Accessed on 12-04-2013, 12:57)..

8 http://www.prefeitura.sp.gov.br/cidade/secretarias/meio_ambiente/parques/regiao_centrooeste/ index.php?p=22396 (Accessed on 06-09-2012, 08:34) 
If ethnographic research manages to bring forth new elements to justify the establishment of protection measures, it is necessary to realize that the strategy cannot be valued for its technical merits alone, since the context is always political and depends on the powers of negotiation of those involved. In this regard, it is worth remembering another demonstration of that power by the residents of Itaim-Bibi, who had already managed to stop the original Parque do Povo project. In 2011, they were able, by means of their association (SOS Itaim Bibi), to veto the sale of the so-called "quarteirão da cultura" (culture block) - a 22 thousand $\mathrm{m}^{2}$ site with a daycare, health center, theatre (Teatro Décio de Almeida Prado), library (Biblioteca pública Anne Frank) and the Associação dos Pais e Amigos dos Excepcionais (APAE) ${ }^{9}$ (The Association of Parents and Friends of the Exceptional)- that the municipal government was offering to a construction company in exchange for the construction of a daycare center.

The concept of immaterial goods is currently used to consider the specificity of those cases; yet when the goods in dispute involve interests other than the "merely" cultural, it is difficult to assure proper protection. This leads to the need to appeal to other instruments to characterize a good as worthy of protection, and to implement measures beyond those currently included in the legislation. One of those measures, for example, is a municipal law from 2004 known as the Neigborhood Plan, which was intended to create solutions to neigborhood problems through the residents' participation in forums and assemblies.

The law had its first important application in 2008 at the neighborhood of Perus in São Paulo's Zona Norte. The inhabitants of the Vila Madalena neighborhood later invoked the Nieghborhood Plan when threatened by the construction of a shopping center in 2012. Initially the "Movimento pela Vila" (The Vila Movement) saw preservation as a way of avoiding the gentrification of the traditional neighborhood: which is a cradle of counterculture, independent filmmaking, and related manifestations of art and culture.

9 APAE (Associação dos Pais e Amigos dos Excepcionais) [www.apaebrasil.org.br] is a network constituted by parents and friends of people with disabilities. APAE supports their social inclusion process. (Accessed on 12-04-2013, 13:10). TN. 


\section{Santana de Parnaíba}

Going back in time a bit further in this attempt to recall experiences in the field of anthropology and heritage, it is worth mentioning the project Santana de Parnaíba: memória e cotidiano (Santana de Parnaíba: memory and everyday life). This was a project that I coordinated in 1984 as part of an advisory service performed for CONDEPHAAT. Santana de Parnaíba is a city located in São Paulo's metropolitan region that has a group of buildings that have federal and state protection because of their architectural importance. But it was also the site of disagreements between residents and technicians from official institutions, which created difficulties in the implementation of some of the measures called for by preservation policies. To diagnose these problems, the president of the council at the time, Antônio Augusto Arantes, appealed to the Documentation and Research Centre for Communitarian Action, presided over at the time by professor Ruth Cardoso, who in turn appointed me to do the job. The report we drafted began as follows:

So-called historical cities are not only the sites where past events are preserved in architectural details and housing. It is necessary to recognize that life continues its course in these places. But the relations of present actors with these sites are not always accounted for by preservation institutions. This omission can be perceived in some of the premises that guide the preservationist practice. The first one is the presupposition that the criteria by which cultural goods are chosen and classified are universal and shared unanimously by all users. The other premise is considering users as mere obstacles to preservation because all too often the relationship between users and preservationist institutions is conflicting, whether it concerns selection criteria, or whether it concerns preservation by state intervention. (Magnani, (1984) 2007b: 283)

Santana de Parnaíba arose in 1580 during the first century of settlement. By 1620 , this colonial village was one of the main points of departure for the bandeirasio thanks to its strategic location on the banks of the Tietê River and along the old indigenous road that led to the backlands of Mato Grosso and Goiás. In the year of our research, it was still a small city

10 Here Bandeiras refers to the expeditions taken by pioneers during the 16 th century in quest of riches, indigenous and to explore the territory. 
with 15,995 habitants and many restored houses and buildings, among them the famous Anhanguera's house from the $2^{\text {nd }}$ half of the $17^{\text {th }}$ century. The daily activities seemed to drift calmly along the three streets of the historic downtown.

The research followed three stages: an initial exploratory stage with our contacts and informal interviews primarily conducted with elderly people, who were always willing to talk about their families and traditions. Afterwards, the data collected during this first stage was organized in a classificatory grid that divided the dwellers in two categories: "insiders" and "outsiders" and further divided the latter category into "foreigners," "artists," and "employees."

Each one of these people had a personal narrative and each had a different understanding of what was this "historical" city's important heritage. However, they all referred to one issue where the differences converged: celebrations. These celebrations were therefore chosen as the object of focus during the last stage of our fieldwork observation, with special attention given to the Corpus Christi commemoration and the procession through streets ornamented like carpets. If we were to account for the whole cycle, we would include the celebration of Saint Ana, the city's patron saint, the Saint Sebastian and Saint Benedict celebrations, the Saint Anthony pilgrimage in the rural district of Surú, and the carnival with its traditional bloco dos fantasmas (ghosts' parade).

Thus, by means of the ethnographic method, it was possible to: 1) describe and analyze the city's everyday life and the changes it suffered during days of celebration, 2) identify the many actors and their relationship with public and private space, 3) track the emergence of conflicts, and 4) trace the impact of this entire scheme upon the understanding of heritage, the central objective of our research.

This was not a peaceful seventeenth-century city; it was embedded in São Paulo's metropolitan region, close to highways and became encompassed within the immense urban periphery. During the research our attention was drawn to the fact that some "foreigners" (Brazilians who have recently arrived from other location and who are supposedly more sensible to the heritage issues) claimed to have "restored" their vacation homes in the historical downtown at the cost of demolishing homes in the suburbs to get "authentic" construction material. 
Hence, notions about heritage vary, making it necessary to address actors and consider their diversity of interests and ideas. On the other hand, the recurrence, shown by the ethnographic research, of discussions of celebrations - the place and time of encounter not only of the many categories of visitors but also of visitors from afar - clearly showed their central importance to the city. The issue was a good place to begin thinking about heritage and its value beyond the everyday life of residents.

\section{Urban Anthropology and Museums}

Another topic of debate is the relationship between museums and anthropology, and one of the first issues that emerges is the notion of representation: what are the criteria used to justify if this or that object, image, fact, etc. could, or should, be included in a catalog? In the specific case of museums dedicated to specific cities, what elements of the multifaceted urban landscape, systems of infrastructure, demographic composition, historical formation, etc. ought to be used to "represent" the diversity and singularity of a city in a museum?

It is helpful to begin the discussion from a common-sense definition of representation. According to the conventional perspective, representation presupposes the existence of a fixed entity in the world that can be apprehended in its totality and afterwards expressed in an immediately recognizable form (in agreement with the rules of a given code, be it verbal, written, pictorial, or otherwise, and maintaining a kind of relationship among them: mimetic, metonymic or metaphorical).

This concept has been discussed by many disciplines, including anthropology. In this particular case, the so-called "crisis of representation," as we already know, was unleashed by virtue of critiques developed inside the movement that came to be known as "Postmodern Anthropology," during the 1960 and 1970s, which discussed the means the discipline used to obtain data and to expose it in the form of classical monographs.

The critiques' main question was whether those monographs, written according to the rules of a "realist" style, reliably or legitimately represented the social organization, lifeways, cosmology and rituals, etc. of the people with whom the anthropologist works. These works did not mention the researcher-native relations and the power of each in these relationships, 
difficulties in language comprehension, the conditions of the anthropologist's rapport with the subjects and environment during fieldwork, and many other factors. These monographs were questioned in their very goal of "representing" the complex and changing reality of a people by means of a fixed and frozen report in the final text, a document that presented research results from the privileged point of view of the researcher.

Without entering into the distinctions of the controversies and developments that this movement produced within the field of anthropology, it is helpful to recall the main issue that was raised and apply it to the central dilemma posed by City Museum ${ }^{11}$. Can the city - principally in its contemporary dimensions, shapes, and dynamics - be "represented" according to the resources, tools, and notions used in traditional museology? Does this not presuppose exactly the same notion of "representation" as was defined above?

The problem becomes more complex when one is looking at the cities known in the literature as "mega-cities," "world cities," and "global cities." According to Mobgin, (2009) these cities share multiple centralities, different ways of life of their inhabitants and the infinity of marks printed on the landscape by institutions and urban equipment.

Looking at an urban situation that had not yet reached such global proportions, the philosopher Jürgen Habermas, in his article "Modern and Postmodern Architecture" ([1983] 1985), already wondered if it is still possible to talk about the city - the one whose prototype was the late Medieval hamlet described by Max Weber (1999), since for Weber urban life was increasingly mediated by "systemic relations, which cannot be given concrete form" while, "the urban agglomerations have outgrown the old concept of the city...." (op. cit.: passim, 327).

Have these cities thus "passed the point," of cities, overgrown in such an exaggerated and disorganized manner as to lead to their defacement in the view of the paradigm of reference. Or, on the contrary, would it not be the case that these cities are inaugurating new arrangements (from common structural forms) by virtue of their scales, functions and the practices of their inhabitants? And, once again, how can we "represent" this diversity?

I believe that the categories developed by urban anthropology can

11 City Museums or, in portuguese "Museu de cidade" refers to a museum that is dedicated entirely to the city and its inhabitants. A City Museum may document and divulge the city's history as well as its present state. TN. 
contribute towards thinking about these new configurations, and consequently create a space to rethink the relationship between cities and museums in a broader perspective. This would allow a collaboration that gives the same importance to both aspects of this relation both in their complexity and their possibilities for interaction. Some concrete experiences presented in the following section will help in elucidating the question.

\section{Museu do Imaginário do Povo Brasileiro (The Museum of the Brazilian People's Imaginary)}

One such experience was my participation on the Board of Curators of the Museu do Imaginário do Povo Brasileiro in 2002 to define the basic concept for the various modules of the exposition. In this case, my participation was limited to the conceptual dimension, contributing to the discussion by emphasizing the need to distinguish between "the imaginary of" and "the imaginary about" the Brazilian people. It was necessary to establish this distinction to avoid confusing conflicting orientations, since choosing one or the other would have a traditional museological proposition as a consequence. If the "Brazilian people's imaginary" was chosen, we would run the risk of taking the direction of a folklore museum. If, on the contrary, we chose the "imaginary about the Brazilian people," there was the danger of privileging the elite's vision of the masses. Despite having already opted, in the title, for one of the alternatives, the debate alerted us to the differences between the two, differences that were considered in the details of specific propositions.

The debate about this distinction led to another antinomy - product versus process - which had consequences for the establishment of the relationship between the permanent expositions and temporary expositions. Typically, museums present their products - oeuvres, objects, and images - to the public with a greater or lesser degree of information about them, but they rarely offer the opportunity to know and discuss the process of their production. Such information is normally the responsibility of more intellectual reflection conducted by specialists restricted to the academic, scholarly fields. All that is left to the public, is a more or less passive contemplation of the products.

The novelty that the Museu do Imaginário do Povo Brasileiro presented was to offer the two angles: the product - mainly in the form of temporary expositions - and the opportunity to access the process of its production, 
meaning the public was provided access to facts that in given (historic, politic, socioeconomic, aesthetic, etc.) conjunctures were responsible for the particular shape the product assumed in the exposition. The nucleus formed by the permanent expositions would create these opportunities while an Integrated Reference Center would give continuity to that reflection, forming a unique and original museological strategy.

\section{Museu da Cidade de São Paulo (The Museum of the City of São Paulo)}

The second experience in which I participated - this time, accompanied by other members of the NAU - was the attempt to found the Museu da Cidade de São Paulo. For several months in 2003 and 2004, a multidisciplinary team met to discuss concepts and creative processes (research and pedagogic activities, among others) for another innovative proposal for which the design and organization had been approved. It would be installed at the Palácio das Indústrias building at the Parque d. Pedro II, in the central region of the city.

Nevertheless, what I want to highlight is not so much the process as the experience that supported the Expedição São Paulo - 450 anos ("The São Paulo Expedition - 450 years). The project was financed by Petrobrás, sponsored by the newspaper Estado de São Paulo, and had logistic support from the Municipal Cultural Secretariat, the Institute Florestan Fernandes, the EXPOMUS ${ }^{12}$ team and the NAU. The experience combined thirty professionals from various areas for a "voyage inside the metropolis," for the anniversary of São Paulo's state capital in January 2004.

Our goal was to come into contact with the diversity of forms of sociability, leisure, religiosity, popular exchange systems, and the functionality of complex systems (such as the subway) that are constitutive of many residents' modes of life in the city of twelve million people. Obviously, this was not an ethnographic research in the technical sense of the word, nor did it pretend to make an exhaustive record. But, a week after professionals from the various areas of knowledge - human sciences, architecture, psychiatry,

12 "The Expomuns [coordinated by museologist Maria Ignez Mantovani] is a company that since 1981 performs museological projects within social, scientific, technological and environment fields (...). National and international museums and cultural institutions, private and corporate collectors and municipal, state and federal public entities are among our main partners and clients." For more information visit: http://www.expomus.com.br/ (Accessed on 09/08/2012, 08:30) 
ethnomusicology, museology, archaeology, arts, and education - traveled through the city along two axles (north-south and east-west), they were able to appreciate and reflect upon the heterogeneity, diversity, and richness of the residents' households that they visited. This diversity emerged not to "survive" the renowned "urban chaos," but to establish their creative and surprising relationships with the city.

The premise that orientated our approach was that despite a recurrent discourse about the violence, inequalities, hardship, and related maladies that are constantly attributed to the metropolis, it would be possible - by means of a "closer and insider" perspective, such as ethnographic examination proposes - to contact the regularities of everyday life and the social networks that support it.

The researchers were accompanied by a team of students - most of them NAU members - who were assigned with collecting the data found and produced during the trip: pictures, interviews, information, addresses, image-usage rights, and even some objects that would enter the future collection of the Museum of the City of São Paulo. They proposed to repeat the trip from time to time to apply the same methodology towards systematically accompanying the dynamics of the city and the necessary renovation of the museological space fated to interact with the city. But... ${ }^{13}$

Two more recent experiences close the series: The Museu do Futebol (The Football Museum) and the Museu da Imigração (Immigration Museum). I will not go into details about the former since there is a thorough account of it in this edition. It is enough to say that in 2010 this Museum - thanks to the initiative of a director and a coordinator, both researchers who were members of NAU - presented a project to FINEP, an organ of the Ministry of Science and Technology, which was given the job of establishing the Documentation Center on Brazilian Soccer. Initiated in 2012, the goal of the Center was to organize a research council and a team of researchers to conduct a broad survey of the practices related to soccer in São Paulo, from professional to amateur. All this information would contribute to the museum's database, which would link to the public (mainly, to the social actors involved) in innovative ways: networks, circuits, and routes.

13 Another initiative that could not be accomplished for political reasons. The expedition nonetheless had four outcomes: an exposition at Galeria Olido, a book Expedição São Paulo, 450 anos: uma vigem por dentro da metrópole, a video under the same title, and a CD with the photos. 
The proposal supposes the elaboration of instruments for research, recording and analysis that link the museological practice to ethnography, to broaden the scopes of storage, cataloging, and exposition. Therefore, multidisciplinary training courses are planned for the Museum researchers as well in the form om continuing education courses, in one way or another, for those who are interested and those who may be carriers of the items, memories, and cultural riches linked to the soccer practice in their neighborhoods and everyday contexts of sociability. The process was accompanied by the NAU along its timeline of collecting and interpreting information from the field.

The participation of NAU at the Museu da Imigração was possible through the invitation of EXPOMUS, which had won the bid for the revitalization project of these traditional facilities. I was responsible for developing the concept for module VI for the exposition that would open the Museum entitled: "Contemporary Migrations." With that concept as a base, the Bom Retiro neighborhood was chosen to exemplify the many nuances and realities of the migration process in São Paulo, going beyond the common treatment of the subject that emphasizes groups of immigrants in the late $19^{\text {th }}$ century and early $2 \mathrm{O}^{\text {th }}$ century. Moreover, through one of its research teams -NAU Migration - NAU conducted research to evaluate the reception, documentation, and representations of the demands of the population living near the Museum in the Mooca neighborhood.

\section{Immaterial Heritage: a street in Londrina}

It has become common to assign each one of the facets of heritage - whether architectural, historical, artistic, archaeological or immaterial - to a specialist in the field who is in charge of defining the criteria, setting the norms, and establishing the proper delimitations. The last to enter into the conversation was the anthropologist, always attentive to the knowledge, festivals, celebrations, practices, and other aspects of traditional folk culture. As is widely known, each one of those facets has a history and form of legitimacy: the first, also known as "brick and mortar," is the most consolidated in heritage practices, whose paradigm promotes emblematic Luso-Brazilian baroque edifications.

There are, as is also known, political and ideological reasons for this choice: the same can be said about the temporal depth, expressed in the 
"historical," which also delimitates the reach and limitations of heritage. The more conservative vision of these facets often excludes more recent cities with their pioneers, settlers, migrants and wooden buildings, as is seen in the following case.

On the other hand, there is an approach that seeks to comprise the diversity of all these aspects, temporalities, and emphases, thus overcoming the difficulties that stem the multiple criteria for defining heritage: it is known by the consecrated expression "cultural heritage." Even if this reference to "culture" points to a broader idea, when it is analyzed carefully, one notices more of a rhetorical, expedient nature than a conceptual one. The debates about culture - and not just within anthropology - are never-ending, which makes it necessary to constantly distinguish theoretical trends and conceptual distinctions to avoid recourse to common sense. Certainly, there is a positive aspect in this regard: while this approach may not easily resolve the multiple issues involved, it points to the need for a wider approach as well as the search for new means to deal with heritage.

Nevertheless, it is necessary to go beyond this theoretical shortcut, which ends up generalizing and dissolving differences, to move forward in the pursuit of characterizing what constitutes heritage, at a more detailed level, as something worth registering and in need of protection. It is necessary to look for innovative criteria and wider frameworks. Once more, I suggest that anthropology can contribute to the debate.

I will now discuss a concrete case to illustrate this issue. I was recently invited to write the presentation text for a compilation entitled, Rua Sergipe: patrimônio cultural Londrinense (Magalhães, 2012), with contributions from many of the members of the IPAC/Londrina (PR). ${ }^{14}$ Each of the authors - architects, historians, and social scientists - focused on the aspect of heritage of their interest. I would like to call attention to one of these aspects.

14 The continuous education project Inventário e Proteção do Acervo Cultural de Londrina - IPAC/ LDA (Inventory and Protection of the cultural heritage of Londrina - IPAC/LDA) was born in 1986 at the Universidad Estadual de Londrina - UEL - as a response to advice offered by José Guilherme Cantor Magnani - who at the time was the Cultural Heritage Coordinator at the State Cultural Secretariat of Paraná. The proposal was to develop a policy to study and intervene in the material and immaterial heritage of Parana's northern region. By selecting Londrina as the starting point for work under the state's cultural heritage policy, Magnani made an instigating choice, because the city and the region are part of a new colonization, and this would demand an updated and broader theoretical and methodological approach towards the concepts and practices in use at the time." (http://www.uel.br/projetos/ipaclda/) 
In this case we were dealing with recuperating the present dynamics of the street Rua Sergipe by showing its vitality and diversity by using the categories of turf, circuit, patch, route and gateway to detect regularities and patterns. There is, certainly, a continuity between the "old" Rua Sergipe, from the glorious times of the founding of the city and the buildings and activities of that era - which for this reason are a source of representations and the current use.

In the book in which she describes the everyday life of a U.S. city in opposition to the artificiality of modernist urbanism (1992), Jane Jacobs uses the interesting expression the "sidewalk ballet" to refer to the vitality of the multiple uses that a street offers to urban dynamics. In terms of heritage, this aspect corresponds, in a way, with a more recent description: immaterial heritage. In the specific case of this street, it embraces a wide range of practices and attributes; meeting places, behaviors, gestures, expressions, bar recipes, games, celebrations. Some are ephemeral, others lack durable material support, and others are somehow the result of a multiplicity of constitutive elements.

These categories allow us to identify, among the presumed chaos, some regularities that grant a particular shape to that street. Moreover, the fieldwork performed and identified new categories, native ones - the "place of pause", among others - that enriched and brought meaningful nuances to the set of categories that already existed.

This initiative attests to the need to transcend the consecrated classifications and face the issue of heritage not just in its contemporaneity, but also to submit it to innovative research projects, using new instruments and perspectives, such as the one this book documents, about a normal, recently established city.

\section{Conclusion}

To finish I will now turn to a text by Ulpiano B. de Menezes, A cidade como um bem cultural (The City as a Cultural Good). It was published in a compilation by the 9 o SR/IPHAN, and followed by guest commentaries from Antonio Augusto Arantes, Edgar Assis Carvalho, Paulo Ormindo de Azevedo and myself (MORI, Victor Hugo; SOUZA, Marise Campos et alii (org.): 2006). I will profit from an observation Menezes made about my commentary (a kind of 
rebuttal), about the category of circuit, to return to the elements I developed throughout this work: 1) anthropology and its relationships with heritage and 2) the city and questions about the forms of museological representations.

In that article, Ulpiano presents the concept of city as a cultural good, in contrast to the more typical idea of "cultural goods in the city" or even the idea of "cultural use," with the latter promoted through a strategy of allocating heritage goods for a supposedly nobler purpose, that of becoming cultural spaces.

To consider the city as a cultural good is a posture that broadens the reach of preservation policies: the idea would be to move beyond cataloging a limited series of elements worthy of protection. In fact, it is the city (as artifact, as a result of a field of forces, and as representation, according to the author) that supports the complex game of meanings created through social processes and that can be condensed and identified, in more specific ways, in this or that place, building, or object.

But it is not the presence of a monument that makes the city worthy of contemplation, realization, or knowledge; it is the presence of a web of meanings that makes this or that "good" noteworthy, and, therefore, worthy of protection. To place the city in the forefront, as a cultural good (as opposed to fragmenting it into the "cultural goods" that compose it), creates space for preservationist practices. We are talking here about a position that offers an alternative to the celebrated analyses of "urban problems."

This argument reminds me of a passage in Tristes Tropiques where LéviStrauss qualifies the city as the "supremely human achievement":

So it is not in any metaphorical sense that we are justified in comparing - as has so often been done - a town with a symphony or a poem; they are objects of a similar nature. The town is perhaps even more precious than a work of art in that it stands at the meeting point of nature and artifice. Consisting, as it does, of a community of animals who enclose their biological history within its boundaries and at the same time mold it according to their every intention as thinking beings, the town, in both its development and its form, belongs simultaneously to biological procreation, organic evolution, and aesthetic creation. It is at one and the same time an object of nature and subject of culture; an individual and a group; reality and dream; the supremely human achievement ([1955] 2012: 124). 
This sentence may seem extemporaneous when faced with the scale and the problems of contemporary megacities. We must keep in mind the context in which it appears: Lévi-Strauss was talking of the Brazilian cities that he saw in the 1930s (São Paulo, the cities in northern Paraná and Goiânia) but also Karachi and Calcutta in India, and the archeological sites of Mohenjo-Daro and Harappa, from 5,00o years ago. Beyond the historical and typological differences, what interests me is to identify the structural principles, perceptible in the longue durée. It is in this sense that the city, in the words of the author, "represents civilization in its most complex and exquisite form" (ibid: 126).

Yet, even if this perspective offers a good antecedent for the idea of the city as an artifact, conceived as a totality, one question remains: how to represent this city? What to choose? I think that the category of circuit recuperates that idea of unity or totality, but

It is obviously neither the kind of totality that evokes an organic, functional, whole, free of conflicts, nor a totality that corresponds, in the case of the city, to its political-administrative boundaries. (...). Nevertheless, to renounce that kind of totality does not mean to assume the extreme opposite position, say, to dive deeply into fragmentation. If we cannot delimit a unique order, it does not mean that there is none; there are particular, segmented orders and there are ordinances, regularities (Magnani, 2002: 16).

If, on one hand, the idea of circuit, points to the idea of totality, it is not a reification. The example I used in my comments to Ulpiano's article - which happens to be about cinema - helps clarify the question of how to represent the apparent paradox of an urban singularity-diversity in a museological space. What interests me, more than an isolated good in itself, is the circuit within which it acquires meaning.

This category (Magnani, 2007) ${ }^{15}$ emerged from the need to name a modality of relationship with the city that did not fit into forms of co-presence between actors and space. If within the limits of a turf and of the patch, it is

15 "It has to do with a category that describes the exercise of a practice or the availability of a specific service through establishments, facilities, and spaces that do not maintain in themselves a relation of spatial continuity, but which are recognized as a whole by its customary users. The notion of circuit also points to a use of the space and of urban facilities - therefore enabling the exercise of sociability through encounters, communication and code switching - yet in a form more independent in relationship to the space, without regard to continuity, as usually occurs with a patch and a turf. But like them, it has an objective and perceptible existence: it can be recorded, described, and located" (Magnani, 2007:20) 
possible to identify a particular slice in the landscape along with its users, the circuit presents another dynamic of interaction between the two. Take for example a kind of cultural practice that presupposes given facilities in its very use, and establishes lasting links between its enthusiasts, creating a community of interests: that of the cinephiles.

It is not about individual consumers: the nature of the activity that brings them together and characterizes them supposes a network based on an exchange of information, critiques and controversies, in short, the search for and exhibition of knowledge. The territorial basis of their practice can shape a contiguous patch, but can also establish a network: it is scattered throughout the city - and not only in the so-called art cinemas that constitute it - but also in libraries, debates, special exhibitions at public institutions and private foundations and at events such as showings, festivals, releases, etc..

The circuit articulates these two dimensions. If this category is applied to other practices - paying attention to the passages and links between them what you find is less the image of something fragmented and isolated within the cityscape, and more a kind of articulated (but not necessarily contiguous) whole that has specific participants, rules, consumer guidelines, patterns of sociability, schedules, etc.. Notice, a propros, the consequence that this kind of reading would have on protection measures that are truly committed to meaningful cultural practices and based on a living and active network of actors. It would be meaningless, for example, to declare the protection of a specific isolated cinema without taking into account the circuit or the patch in which it is located.

Returning to cinema, we need to consider not only the space involved, but the history: in the case of São Paulo there is no way to ignore the importance of the boca do lixo, a quadrangle in the Luz neighborhood and a center of the film industry in the 1920 and 1930s. Its production was characterized first by low cost films and later by the pornochanchada of the 1970s. Yet we must consider much more: the old and imposing movie theatres downtown, in the so-called cinelândia of the 1940 and 1950s - most of them still in activity exhibiting porn films; the Companhia Cinematográfica Vera Cruz, the most important Brazilian film studio in the 1950s; Amácio Mazzaropi’s filmography, filled with one blockbuster after another until the 1970s; the Cinemateca Brasileira with its fine catalog; the art cinemas; the screening rooms in shopping centers, and finally the role of the The São Paulo 
International Film Festival, already in its $35^{\text {th }}$ edition. An isolated good - this or that theater, listing, or facility - acquires meaning when it is incorporated into a circuit or is at the interior of a patch, which in this case may be considered to be its "surroundings" in the technical jargon.

At the boca do lixo region, you have a consistent circuit, one in which each point contributes with its specificity to a practice whose common denominator - the fruition of cinema - is fostered by the limitless number of services constituted over time and distributed through the cityspace. The same logic can be applied to the patch, as is found at the corner between Avenida Paulista and Rua da Consolação when the Cine Belas Artes and the Riviera bar were its main points - and which have now moved to the Baixa Augusta region and Rua Frei Caneca. In these cases, the clearly recognizable routes of the visitors appear at the level of walking, which is different from what happens with the circuit because the latter does not depend upon a spatial continuity.

In this way, whether as a question of heritage to be identified, protected, and preserved - as we saw in the cases of the Cine Belas Artes, the Parque do Povo, Santana de Parnaíba, and Rua Sergipe in Londrina, or with the challenges of museology put forth by the dynamics and diversity of the cities in the cases of the Museu da Cidade de São Paulo, the Museu do futebol, and the Museu do Imaginário do Povo Brasileiro, anthropology, and specially urban anthropology, with its distinct method of ethnography, categories of analyses, and research strategies, may open a fruitful dialog with the disciplines traditionally engaged with the different dimensions of heritage and museology.

Translated by Diana Paola Gómez Mateus and revised by Craig William Schuetze

Accepted for publication on February 22, 2013.

\section{Bibliography}

CESÁRIO, Ana Cleide C. et alli. 2012. "Sergipe, a rua de todas a compras". In: Leandro Henrique Magalhães (org.), Rua Sergipe: patrimônio cultural londrinense. Londrina: UniFil. pp. 75-101.

HABERMAS, Jürgen. 1985 "Modern and postmodern architecture”. Helena

Tsoskounoglou (trad.). In: John Forester (ed.). Critical theory and public life. 
Massachusetts: MIT Press. pp. 317-329

Jacobs, Jane. 1992. The death and life of great american cities. Nova York: Vintage. LÉVI-STRAUSS, Claude. 2012 [1955]. Tristes tropiques. John Weightman and Doreen Weightman (trads.). New York: Penguin Classics. Reprint edition. MAGALHÃES, Leandro Henrique. 2012. Rua Sergipe: patrimônio cultural londrinense. Londrina: UniFil.

MAGNANI, J. Guilherme C. \& MORGADO, Naira. 1996. "Tombamento do Parque do Povo: futebol de várzea também é patrimônio”. Revista do Patrimônio Histórico e Artístico Nacional, 24: 175-184.

MAGNANI, J. Guilherme C. (org.). 2004. Expedição São Paulo 450 anos - uma viagem por dentro da metrópole. São Paulo: Secretaria de Cultura do Município de São Paulo/ Instituto Florestan Fernandes.

MAGNANI, J. Guilherme C. 2007. "Introdução: circuito de jovens”. In: J. Guilherme C. Magnani \& Bruna Mantese (orgs.), Jovens na metrópole: etnografias de circuitos de lazer, encontro e sociabilidade. São Paulo: Terceiro Nome (Col. Antropologia Hoje). pp.15-22.

MAGNANI, J. Guilherme C. 2007b. "Santana de Parnaíba: memória e cotidiano”. In: Regina Abreu; Mário de S. Chagas \& Myrian S. Santos (orgs.), Museus, coleções e patrimônios: narrativas polifônicas. Rio de Janeiro: Garamond Universitária/ MINC. pp. 283-323.

MENEZES, Ulpiano Bezerra. 2006. "A cidade como bem cultural: áreas envoltórias e outros dilemas, equívocos e alcance da preservação do patrimônio ambiental urbano". In: Victor Hugo Mori; Marise Campos Souza et alli (org.), Patrimônio: atualizando o debate. São Paulo: 9a SR/ IPHAN. pp.33-76.

MONGIN, Olivier. 2009. A condição urbana: a cidade na era da globalização. São Paulo: Estação Liberdade.

TORRES, Lilian de Lucca. 2008. "Programa de paulista: lazer no Bixiga e na avenida Paulista com a rua da Consolação”. In: J. Guilherme C. Magnani \& Lilian Torres. Na metrópole: textos de antropologia urbana. $3^{a}$ ed. São Paulo: Edusp/ Fapesp. pp. 54-87.

WEBER, Max. 1999. Economia e sociedade. Brasília: Editora da UNB. vol. 2. 